\title{
SOCIO-ECONOMIC IMPACTS \\ OF GKI ACTIVITY
}

By

David L. Hutchinson

GEOKINETICS INC.
Buchanan Field Road
Concord, CA 94520

GEOKINETICS INC.
280 Buchanan Field Road
Concord, CA 94520

GEOKINETICS INC.
80 Buchanan Field Road
Concord, CA 94520

\author{
David i. Hutchinson
}

This book was prepared as an account of work sponsored by an agency of the United States Government. Neither the United States Government nor any agency thereof, nor any of their employees, makes any werranty, express or implied. or assumes any legal liability or respansito process disclosed, or completeness, or usefulness of any information. appan rights. Reference herein to any specific represents that its use wolld no ing an trade name, trademark, manufacturer, or otherwise, does not necessarily constitute or imply its endorsement, recommendation, or favoring by the United States Government or any agency thereof. The views and opinions of authors exprest.

\section{ANSTER}

May 1979

\begin{abstract}
PREPARED FOR THE UNITED STATES DEPARTMENT OF ENERGY
Under Cooperative Agreement 非E-FC20-78LC10787
\end{abstract}




\section{DISCLAIMER}

This report was prepared as an account of work sponsored by an agency of the United States Government. Neither the United States Government nor any agency Thereof, nor any of their employees, makes any warranty, express or implied, or assumes any legal liability or responsibility for the accuracy, completeness, or usefulness of any information, apparatus, product, or process disclosed, or represents that its use would not infringe privately owned rights. Reference herein to any specific commercial product, process, or service by trade name, trademark, manufacturer, or otherwise does not necessarily constitute or imply its endorsement, recommendation, or favoring by the United States Government or any agency thereof. The views and opinions of authors expressed herein do not necessarily state or reflect those of the United States Government or any agency thereof. 


\section{DISCLAIMER}

Portions of this document may be illegible in electronic image products. Images are produced from the best available original document. 
The Geokinetics In-Situ Oil Shale Project is a cooperative venture of Geokinetics Inc. (GKI) and the U.S. Department of Energy. The objective of the project is to develop and utilize a true in-situ process for recovering shale oil using a fire front moving in a horizontal direction.

The project site is located 70 miles south of Vernal, Utah, on Section 2, T14S, R22E, Uintah County, Utah (see figure 1). Because of the remote location of the site, and its poor accessibility over unpaved roads, a field camp (Kamp Kerogen) was established to support the project and provide living quarters for the field crew.

GKI recognizes that uncoordinated rapid population growth can have devastating impacts on the socio-cultural structure and public service delivery system of a community. Therefore, GKI's goals have been to:

1. Assess the potential socio-economic impacts GKI activity could have on the Uintah Basin, and

2. Develop and implement strategies to avoid or mitigate significant adverse impacts.

The purpose of this report is to assess the potential socioeconomic impacts of GKI activities on Uintah Basin. This report fulfills objective 1 of the Socio-economic section of GKI's Environmental Research Plan (ERP).

The Uintah Basin of East-Central Utah consists primarily of Uintah and. Duchesne counties, bordered on the south by the Book Cliff Mountains and on the north by the southern drainage of the Uinta Mountains. This study was limited to assessing impacts on the Uintah Basin because natural boundaries tend to isolate the Basin; in fact, Kamp Kerogen is accessible only through the Basin during the winter. In addition, GKI maintains an office in Vernal, and does most hiring and purchasing through Basin sources.

Potential impacts on soc10-economic conditions in the. Uintah Basin are limited by the scope of GKI operations. Approximately 30 persons were employed by GKI in 1978, and gross expenditures were less than $\$ 1.5$ million. Comparing these figures with Basin population and gross taxable sales figures can give an idea of the relative importance of GKI activities. 
In 1978, the population of Uintah and Duchesne counties was nearly 30,000.1: GKI employees represented $0.1 \%$ of the Basin population. 1978 Gross Taxable Sales were estimated to be $\$ 167.192$ million for the Uintah Basin. 2 GKI expenditures totaled less than $1 \%$ of gross taxable sales, even if it: is assumed that all expenditures went to Basin businesses.

GKI employment and expenditures are likely to increase in the years ahead, but projected increases will have insignificant socio-econmic impacts on local communities. Most employees will be hired locally and reside at Kamp Kerogen, so no significant increase in the Basin population will result from increasing GKI activities.

However, some employees will already own and others will seek to purchase homes in the area. In addition, other taxable property, as well as groceries, personal and household items will:be purchased from local merchants, primarily in Vernal and Roosevelt. Resulting impacts; though insignificant, will be pọsitive.

Several years ago, Utah State University researchers developed estimates of population changes and impacts associated with employment growth in Uintah County. 3 Their report indicated that a project increasing basic employment by 400 persons would have minor impact, but would increase the tax base of the county. Increases in basic employment of up to 3000 persons would have substantial impact and warrant careful advance planning, but should not present unsolvable problems to the area. ${ }^{4}$ Other socio-economic impact studies have reported favorably on Uintah Basin growth resulting from oil shale development. 5

It is unlikely that GKI employment will approach, let alone exceed, the threshold level of 400 employees. In addition, GKI growth will be incremental and gradual, even to commercial scale operations. This leads us to conclude that GKI operations will have minimal adverse impact upon the Uintah Basin and in: fact will probably have a net positive impact on the Basin. This conclusion is bolstered by City, County and Regional officials who in conversation have expressed no anxiety with GKI's development plans.

The Uintah Basin Association of Governments (UBAG) is the principal planning agency concerned with growth in the Uintah Basin and has establislied an Energy Planning office to assist in managing growth and mitigating adverse socio-economic impacts. GKI will continue to cooperate with UBAG and other local authorities to insure that company acitvities contribute in a positive manner to the growth and well-being of the Uintah Basin. 


\section{POOTNOTES}

1. Based on "County Economic Facts" for Duchesne County, 1977. and vintah County, 1978, published by the litah Industrial Development Division.

2. ibid.

3. Logan, ì., ì. Hiseman, S. Albrecht, and B.D. Gardner; Anticipated Scicio-Economic Impacts in the Uintah Basin of Utan Resulting from 0il Shale Development in the Area; Report on a study funded by the Bureau of Land Hanagement, with matching support from Utah State University.

4. ibid, p.11.

5. Crawford, A. Berry, Herbert H. Fullerton, and W. Cris Lewis of lestern Environmental Associates, Inc. SocioEconomic Impact Study of Oil Shale Development in the Uintah Basin prepared for the White River Shale Project. November, 1975 : 


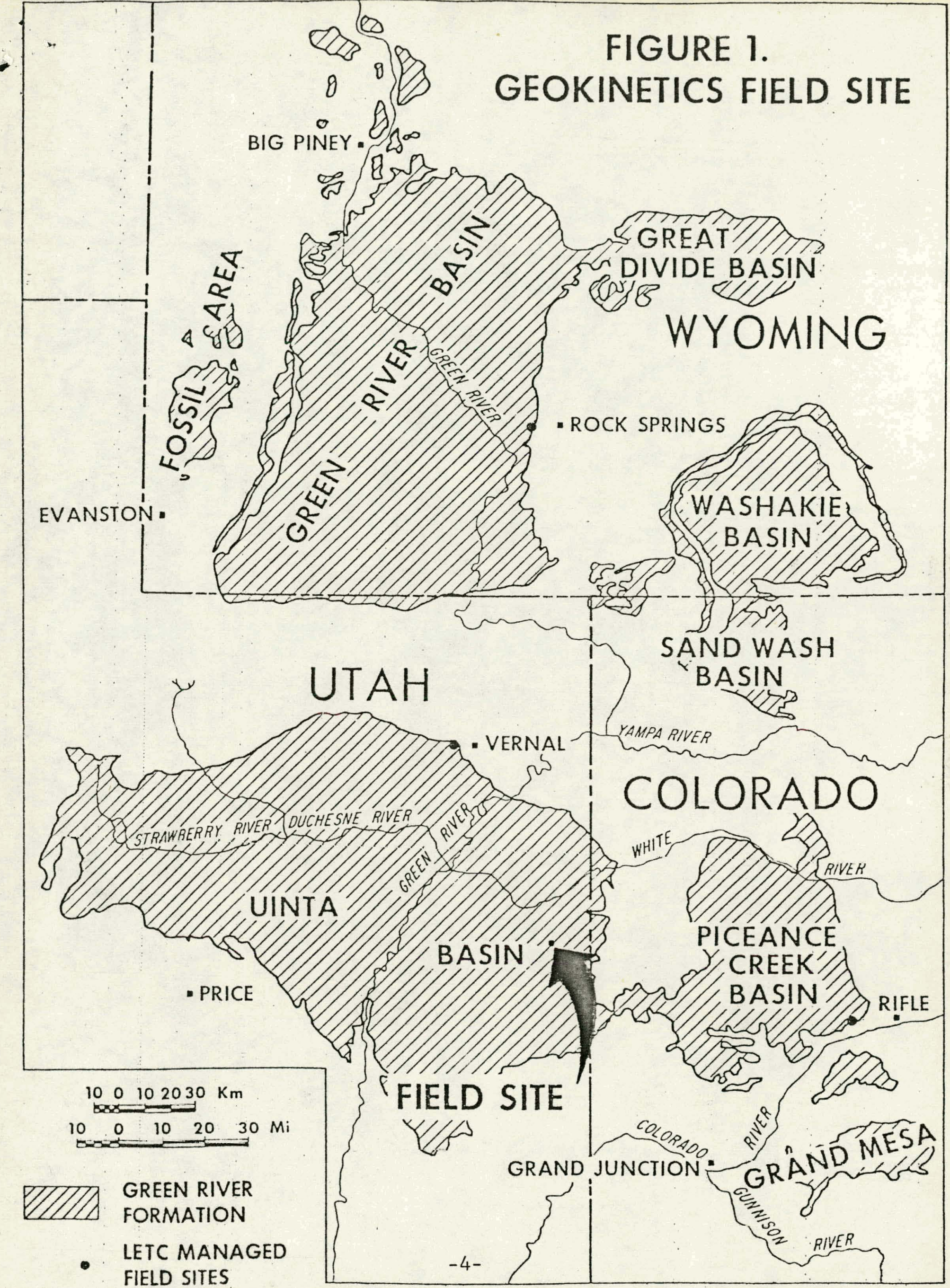

